\title{
Thiazolidinediones decrease vascular endothelial growth factor (VEGF) production by human luteinized granulosa cells in vitro
}

\author{
Divya K. Shah, M.D. ${ }^{a}$, K.M.J. Menon, Ph.D. a,b, Lourdes M. Cabrera, M.S. ${ }^{a}$, Anjel Vahratian, \\ Ph.D., M.P.H. ${ }^{a}$, Shahryar K. Kavoussi, M.D., M.P.H. ${ }^{\text {a,c }}$, and Dan I. Lebovic, M.D., M.A. ${ }^{d}$ \\ a Department of Obstetrics and Gynecology, University of Michigan, Ann Arbor, Michigan \\ b Department of Biological Chemistry, University of Michigan, Ann Arbor, Michigan \\ c Department of Obstetrics and Gynecology, Division of Reproductive Endocrinology and Infertility, \\ University of Michigan, Ann Arbor, Michigan \\ d Department of Obstetrics and Gynecology, Division of Reproductive Endocrinology and Infertility, \\ University of Wisconsin, Madison, Wisconsin
}

\begin{abstract}
Objective-To determine the effect of thiazolidenedione derivatives (TZDs) on VEGF production by human luteinized granulosa cells and the morphologic development of murine embryos.

Design-Prospective, experimental, in vitro and in vivo study.

Setting-Research laboratory.

Patients-Follicular aspirates from ten women undergoing oocyte retrieval.

Interventions-Isolated human granulosa cells were treated with a DMSO control or ciglitazone, in the presence and absence of an hCG stimulus. Embryos extracted from superovulated B6C3F1 female mice were cultured in the presence of DMSO or pioglitazone.

Main Outcome Measures-VEGF concentrations at 24 and 48 hours. Morphologic development of murine embryos at 96 hours.

Results-Following an hCG stimulus, treatment with $20 \mathrm{uM}$ or $40 \mathrm{uM}$ ciglitazone decreased VEGF production in a statistically significant manner at both time intervals. Blastocyst development at 96 hours did not significantly differ between untreated zygotes and those treated with pioglitazone.

Conclusions-Ciglitazone significantly decreased VEGF production by human granulosa cells in an in vitro model. Pioglitazone did not adversely impact the development of cultured murine embryos. Although mechanistic evidence is not provided, the pivotal role of VEGF in ovarian hyperstimulation syndrome prompts investigation of TZDs as a novel treatment for this condition.
\end{abstract}

Corresponding author: Divya Kelath Shah, MD, Department of Obstetrics and Gynecology, L4000 Women's Hospital, 1500 East Medical Center Drive, Ann Arbor, MI 48109, Phone: (734) 657-4116, Fax: (734) 647-1006, Email: divyas@ med.umich.edu.

Work presented at: American Society for Reproductive Medicine, $63^{\text {rd }}$ Annual Meeting, Washington D.C., October 2007. [Abstract \#O-105]. Recipient of Resident In-Training Award and Candidate for General Program Prize.

Publisher's Disclaimer: This is a PDF file of an unedited manuscript that has been accepted for publication. As a service to our customers we are providing this early version of the manuscript. The manuscript will undergo copyediting, typesetting, and review of the resulting proof before it is published in its final citable form. Please note that during the production process errors may be discovered which could affect the content, and all legal disclaimers that apply to the journal pertain. 


\section{Keywords}

Thiazolidinediones; PPAR-gamma; VEGF; granulosa cells; OHSS

\section{Introduction}

The female reproductive tract is one of a few adult systems in which angiogenesis occurs as a normal process, one that is essential for menstrual cyclicity, placentation, and support of a growing embryo (1). In contrast to that observed during pathologic tumor growth, the angiogenic process in female reproductive tissues is limited and therefore must be tightly regulated. While a number of potential regulators of angiogenesis have been identified, vascular endothelial growth factor (VEGF) has emerged as one of the most significant.

Evidence supports the regulatory function of VEGF in nearly all stage of follicular angiogenesis - from development of the antral follicle to formation and maintenance of the corpus luteum (2-5). Despite VEGF's integral role in physiologic ovarian function, its overproduction may result in pathologic conditions such as ovarian hyperstimulation syndrome (OHSS). In its most severe form, OHSS is characterized by massive cystic enlargement of the ovaries associated with increased capillary permeability and a third space fluid shift - leading to the classic triad of ascites, pleural effusion, and hemoconcentration (2). Some groups have focused on the use of peripheral blood VEGF concentration as a predictor of OHSS during in vitro fertilization cycles (6). Serum and follicular fluid VEGF concentrations have been shown to be significantly elevated in patients who developed severe OHSS compared to those who did not, suggesting a role for VEGF in the pathogenesis of this condition (7).

Peroxisome proliferator activated receptors (PPAR) are a newly characterized class of ligandactivated transcription factors belonging to the nuclear receptor family. Three PPAR isotypes have been identified, and are commonly designated PPAR $\alpha, \operatorname{PPAR} \beta$, and PPAR $\gamma$. PPAR $\gamma$ is found in adipose tissue, liver, spleen, colon, adrenal glands, and muscle tissue (8), where its actions were originally thought to be limited to the control of lipid metabolism and glucose homeostasis. Recent studies, however, have identified PPAR isotypes in cells of the immune system as well as those of the reproductive tract, including the ovary, mammary glands and the uterus (9). In the ovary, PPAR $\gamma$ is expressed most strongly in the granulosa cells, and less strongly in theca cells and corpora lutea (10).

Thiazolidinedione derivatives (TZDs), such as pioglitazone, are synthesized ligands of PPAR $\gamma$ that are approved as oral antihyperglycemic agents as therapy for non insulin dependent diabetes mellitus. More recently, TZDs have been found to decrease VEGF production by activating PPAR $\gamma$ in tumor endothelial cells, thereby inhibiting tumor growth and metastasis (11). TZDs have been shown to similarly suppress VEGF gene expression in human endometrial cells (12).

The inhibition of VEGF expression by PPAR $\gamma$ ligands in these other cell types prompted us to investigate if TZDs can similarly mitigate VEGF expression in human granulosa cells. We predicted that VEGF concentrations would be diminished in the media collected from luteinized granulosa cells subjected to treatment with the commercially available TZD ciglitazone, as compared to placebo-treated controls. For TZDs to realistically be used as a prophlyaxis or therapy for OHSS, their safety profile with respect to embryogenesis would have to be established. We therefore investigated the safety of the FDA-approved TZD pioglitazone on the morphologic development of murine embryos in an in vitro model. 


\section{Materials and Methods}

\section{Granulosa cell isolation and culture}

Ovarian follicular aspirates were obtained from ten women undergoing oocyte retrieval as part of an in vitro fertilization program. Ovulation was induced by sequential treatment with recombinant human FSH (Gonal F), followed by administration of hCG. Follicles were aspirated 36 hours after hCG administration and the follicular fluid donated to our study. The use of discarded follicular fluid and associated granulosa cells had been given exemption from continuing review by the University of Michigan Medical Institutional Review Board based on Federal Regulations 45 CFR 46.101 (b). The follicular fluid from each individual was pooled and centrifuged at $500 \mathrm{~g}$ for 5 minutes. The supernatant was removed, and the cell pellets resuspended in $4 \mathrm{ml}$ McCoy's 5A medium, pH 7.4 (Invitrogen, Grand Island, NY). The suspension was layered over 3ml Ficoll-Paque Plus (Amersham Biosciences, Uppsala, Sweden) and centrifuged at 500 $\mathrm{g}$ for 30-40 minutes to isolate the granulosa cells from the sample (13). The granulosa cells were removed from the interface and washed twice. Cells were counted with a hemocytometer, and cell viability determined using Trypan Blue exclusion, which was found to be consistently greater than $90 \%$. Isolated granulosa cells from each individual were cultured in triplicate in separate 24 well tissue culture plates at a density of 50,000 viable cells in $1 \mathrm{ml}$ McCoy's 5A medium supplemented with $10 \%$ fetal calf serum, glutamine $(0.0015 \%)$, gentamycin $(50 \mu \mathrm{g} / \mathrm{ml})$, and nystatin $(2 \mathrm{U} / \mathrm{ml})(13,14)$.

\section{VEGF measurement}

Culture media was replaced with a serum-free media 24 hours after plating. On day 2 of culture, the cells were treated with a DMSO control, $10 \mathrm{uM}, 20 \mathrm{uM}$, or $40 \mathrm{uM}$ ciglitazone (Cayman Chemical, Ann Arbor, MI, USA). Molar concentrations of the commercially available ciglitazone were calculated to reflect standard clinical dosing of pioglitazone, with a $40 \mu \mathrm{M}$ concentration of ciglitazone corresponding to serum levels achieved with a $45 \mathrm{mg}$ daily dose of pioglitazone (15). Cells were cultured both in the presence and absence of $2.7 \mathrm{uM} \mathrm{hCG} \mathrm{CR}$ 127 (purchased from Dr. Al Parlow, University of California Los Angeles through NIDDK hormone distribution program) in a manner consistent with the published literature $(3,13)$. Medium was harvested 24 and 48 hours post-treatment and frozen at $-20^{\circ} \mathrm{C}(11)$. VEGF protein concentrations were measured in duplicate by enzyme-linked immunosorbent assay (ELISA) using R\&D Systems Quantikine kits (R\&D Systems, Minneapolis, MN, USA) using 1 part assay diluent to 4 parts sample as per the manufacturer's instructions.

\section{Cell proliferation assay}

Isolated granulosa cells from four individual patients were plated at a standard concentration of 50,000 cells per well and treated with a DMSO control, $10 \mathrm{uM}, 20 \mathrm{uM}$, or $40 \mathrm{uM}$ ciglitazone as described above. Mean cell numbers were assessed using Trypan Blue exclusion after 48 hrs of treatment.

\section{Murine embryo isolation and culture}

Six to eight-week-old B6C3F1 female mice (Charles River Laboratories, Wilmington, MA, USA) were superovulated by an intraperitoneal administration of $10 \mathrm{IU}$ of pregnant mare serum gonadotropin (Sigma-Aldrich, St. Louis, MO, USA) by injection, followed 44 hours later with an injection of $10 \mathrm{IU}$ of human chorionic gonadatropin (Sigma-Aldrich, St. Louis, MO, USA). After hCG injection, females were caged individually with mature B6C3F1 male mice of known fertility. Presumptive zygotes were collected 21 hours later by dissecting oviducts in Hepes-buffered human tubal fluid (HTF-H) medium (Irvine Scientific, Santa Ana, CA, USA), supplemented with $0.1 \%$ hyaluronidase to remove surrounding cumulus cells. Zygotes were washed three times in HTF-H medium supplemented with $0.3 \%$ of bovine serum albumin 
(BSA) (Fisher BioReagents, Pittsburgh, PA, USA). All procedures performed on animals were approved by the University of Michigan Animal Care and Use Committee.

Embryos were cultured in $50 \mu$ drops of Potassium Simplex Optimized Media (KSOM + AA) (Chemicon International, Billerica, MA, USA) overlaid with mineral oil (Irvine Scientific, Santa Ana, CA). Embryos were randomly allocated in groups of 15 embryos per drop between five treatment groups: plain KSOM media (control \#1), KSOM with $1 \mu \mathrm{L}$ of DMSO (control \#2), or KSOM with $1 \mu \mathrm{M}, 2 \mu \mathrm{M}$, or $4 \mu \mathrm{M}$ pioglitazone (purchased from investigational drug service at University of Michigan, Ann Arbor, MI, USA) dissolved in DMSO. Molar concentrations of pioglitazone were calculated to reflect standard clinical dosing of the drug, with a $4 \mu \mathrm{M}$ concentration corresponding to the maximum $45 \mathrm{mg}$ daily dose. Culture dishes were placed in a humidified environment of $5 \% \mathrm{CO} 2$ in air at $37^{\circ} \mathrm{C}$ for 4 days. Embryos were inspected for viability at 24 hour increments and the morphologic stage of embryo development was assessed at 96 hours. All experiments were repeated in triplicate for a total $\mathrm{N}$ of 100 embryos per treatment group.

\section{Statistical analysis}

All statistical analyses were performed using SAS Statistical Software Version 9.1 (SAS Institute Inc., Cary, NC). A test of normality was performed using the UNIVARIATE procedure in SAS. As the granulosa cell proliferation and VEGF data were not normally distributed, comparisons across treatment groups were made using a non-parametric approach, specifically the NPAR1WAY procedure in SAS. Statistical significance was assessed using the Kruskal-Wallis test. Pairwise comparisons for the VEGF concentration analysis were performed with a Bonferroni adjustment $(0.05 / 12$ for a significance level of $\alpha=0.004)$. Results are expressed as mean $\pm \mathrm{SE}$ as specified in the text and figure legends.

As the murine blastocyst data were found to be normally distributed, comparisons of the percentage of murine embryos that achieved development to the blastocyst stage across treatment groups were made using a series of chi-square tests to generate p-values. A p-value $<0.05$ was considered statistically significant.

\section{Results}

VEGF secretion by cultured granulosa cells increased with time, from 24 to 48 hours. VEGF secretion was also uniformly higher in those cells cultured in the presence of additional hCG. At the 24 hour timepoint, treatment with $20 \mathrm{uM}$ or $40 \mathrm{uM}$ ciglitazone decreased VEGF secretion in a statistically significant manner in those cells cultured in the presence of an hCG stimulus (Figure 1). Each dose of ciglitazone also decreased VEGF secretion in the absence of hCG, but none achieved statistical significance. At 48 hours, treatment with $20 \mathrm{uM}$ or $40 \mathrm{uM}$ ciglitazone achieved a statistically significant decrease in VEGF secretion as compared with a DMSO control (Figure 2). The effect was independent of whether the cells were cultured in the presence or absence of hCG. In those cells cultured in the presence of hCG, the $10 \mathrm{uM}$ dose of ciglitazone was also able to achieve a statistically significant decrease in VEGF. The effect was more pronounced with higher doses of ciglitazone, with a $45 \%$ diminution in VEGF production when cells were treated with $10 \mathrm{uM}$ ciglitazone $(1987 \mathrm{pg} / \mathrm{ml}$ vs. $1091 \mathrm{pg} / \mathrm{ml}$, $\mathrm{P}<0.001$ ) as compared to a $70 \%$ decrease noted after treatment with $40 \mathrm{uM}$ ciglitazone (1987 $\mathrm{pg} / \mathrm{ml}$ vs. $598 \mathrm{pg} / \mathrm{ml}, \mathrm{P}<0.001)$.

Recognizing that the inhibitory effect of ciglitazone on VEGF production could potentially be related to an inhibition of cell growth, we conducted subsequent experiments to assess the impact of VEGF on granulosa cell proliferation. There was no significant differences noted in the degree of granulosa cell proliferation between the various ciglitazone treatment groups, 
with each group demonstrating an approximately $200 \%$ increase ( $\mathrm{P}>0.1$ for all comparisons) in total cell number over 48 hours (Table 1).

Total blastocyst development at 96 hours did not significantly differ between untreated zygotes and those treated with a DMSO control, $1 \mathrm{uM}, 2 \mathrm{uM}$, or $4 \mathrm{uM}$ pioglitazone $(\mathrm{P}>0.1$ for all comparisons). Sixty-one to sixty-eight percent of zygotes in each treatment group were noted to progress to or beyond the early blastocyst stage (Figure 3).

\section{Discussion}

We have shown that the commercially available TZD, ciglitazone, significantly decreased VEGF production by human granulosa cells in an in vitro model. The greatest inhibitory response was observed when using a $40 \mathrm{uM}$ dose of ciglitazone. Our findings were consistent with existing data that demonstrated inhibition of VEGF expression by PPAR $\gamma$ ligands in a variety of other cell types $(11,12,16)$. Given VEGF's pivotal role in the pathogenesis of OHSS, our findings suggest a theoretical role for PPAR $\gamma$ ligands in prevention of this condition.

Data accumulated over the past decade strongly implicates VEGF as the primary promoter of vascular permeability in OHSS $(17,18)$. Subsequent studies have focused on identifying the cell types in which VEGF is produced and examining its expression during ovarian stimulation. VEGF expression has been confirmed in human granulosa cells, $(4,19)$ where it has been shown to increase in response to administration of hCG $(20,21)$. Recent work has also identified elevated levels of VEGF in circulating peripheral blood mononuclear cells in women with OHSS, suggesting a role for immune cells in the pathogenesis of the disease (22).

Comparatively little is known about the mechanism by which VEGF exerts its clinical effects, and studies examining prevention of OHSS via inhibition of VEGF production have frequently suffered from a lack of mechanistic support. Endothelial adherens junctions and the adhesion molecule vascular endothelial (VE)-cadherin have recently been investigated as downstream targets for VEGF signaling (23), although potential applications of this pathway in the clinical setting have not been explored. The specific VEGFR-2 inhibitor SU5416 (Z-3-[(2,4dimethylpyrrol-5-yl)methylidenyl]-2-indolinone) has been shown to decrease vascular permeability following hCG stimulation in a rodent model of OHSS (18), but its side effect profile and interference with early pregnancy development limit its clinical utility (24). The use of low-dose dopamine agonists to block VEGF mediated vascular permeability without altering VEGFR-2 dependent angiogenesis is emerging as a potential means of preventing OHSS in a clinical setting (25-27). Our data indicated that TZDs decreased VEGF production by cultured granulosa cells, and treatment with FDA-approved pioglitazone did not adversely impact the morphologic development of cultured murine embryos in vivo. Given the widespread use of orally administered TZDs in clinical practice, we propose these PPAR $\gamma$ ligands as an alternate and novel means of inhibiting VEGF production and perhaps abrogating the clinical syndrome of OHSS.

It should be mentioned that ciglitazone, the compound used in our granulosa cell experiments, is a commercially available TZD that is not in clinical use. Secondary to its ease of availability, however, ciglitazone is widely used as an index drug for this class in the scientific literature investigating actions of PPAR $\gamma(16)$, thus prompting its use in our initial studies. During the time period that we conducted our experiments, new evidence emerged that raised concern about differential safety profiles between various TZDs. The widely publicized 2007 metaanalysis implicating rosiglitazone as posing an increased cardiac ischemic risk for type 2 diabetics (28) prompted us to conduct the remainder of our murine embryo experiments using pioglitazone, a clinically utilized TZD that has been shown to have a favorable safety profile with respect to cardiovascular health (29). As existing literature suggests that all members of 
the TZD drug class appear to share a common mechanism of action via PPAR $\gamma(30,31)$, we can postulate that pioglitazone and ciglitazone would have similar inhibitory effects on VEGF production in granulosa cells. Subsequent experiments would have to confirm this assumption.

Earlier studies have demonstrated a two to three-fold increase in VEGF production by granulosa cells cultured in the presence of $\mathrm{hCG}(3,21)$. There seems to be disagreement on the time course of this effect, with some groups noting maximal increase in VEGF secretion after 3 hours of exposure to hCG (21) and others noting no increase prior to day 4 of culture (3). Our data demonstrate a significant increase in VEGF secretion by granulosa cells cultured in the presence of hCG, but the effect is of a smaller magnitude than previously reported. This difference is most likely attributable to the timing of our VEGF measurements, which were performed at 24 and 48 hours of culture following an initial 48 hour acclimation period. Our previous studies have shown that luteinized granulosa cells require 48 hours to recover from the initial downregulation of the LH receptor following exogenous hCG administration (13). As the granulosa cells were cultured for an additional 2 days, we attribute the minimal hCG response to decreased levels of $\mathrm{LH}$ receptors in these cells secondary to the prolonged duration of culture.

At the present time, no mechanistic evidence has been provided by our study. Follow up experiments will need to thoroughly explore the mechanisms by which TZDs exert their inhibitory effect on VEGF and whether TZDs have any effect on granulosa cell steroidgenesis.

The safety of TZDs in early pregnancy has been suggested by the literature. Murine studies have demonstrated that rosiglitazone does not adversely impact embryo or neonatal development (32) and may even exert positive effects on blastocyst quality in female mice with diet-induced obesity (33). First-trimester use of rosiglitazone in a small case series of pregnant women with polycystic ovary syndrome demonstrated no evidence of developmental or congenital abnormalities (34). The clinical utility of TZDs in ameliorating OHSS may be best initially studied in a population of oocyte donors until the long term safety of the compounds in fetal development can be further established in human studies.

This study is the first to our knowledge to identify PPAR $\gamma$ ligands as inhibitors of VEGF production by luteinized granulosa cells. Our data indicates that TZDs are not cytotoxic to granulosa cells, and do not adversely impact the morphologic development of cultured murine embryos. These findings suggest a potential role for TZDs in the amelioration or prevention of OHSS.

\section{Acknowledgments}

The authors would like to acknowledge Dr. Gary Smith for his support and advice in the execution of the embryo morphology experiments.

Financial support of the study:

NIH 5K23HD043952-02 (DIL)

NIH R37HD06656 (KMJM)

\section{References}

1. Kaczmarek MM, Schams D, Ziecik AJ. Role of vascular endothelial growth factor in ovarian physiology - an overview. Reprod Biol 2005;5(2):111-137. [PubMed: 16100562]

2. Rizk B, Aboulghar M, Smitz J, Ron-El R. The role of vascular endothelial growth factor and interleukins in the pathogenesis of severe ovarian hyperstimulation syndrome. Human Reprod Update 1997;3(3):255-266. 
3. Lee A, Christenson LK, Patton PE, Burry KA, Stouffer RL. Vascular endothelial growth factor production by human luteinized granulosa cells in vitro. Hum Reprod 1997;12(12):2756-2761. [PubMed: 9455848]

4. Kamat BR, Brown LF, Manseau EJ, Senger DR, Dvorak HF. Expression of VPF/VEGF by human granulosa and theca lutein cells: role in corpus luteum development. Am J Pathol 1995;146:157-165. [PubMed: 7531945]

5. Zimmermann RC, Hartman T, Kavic S, Pauli SA, Bohlen P, Sauer MV, et al. Vascular endothelial growth factor receptor 2-mediated angiogenesis is essential for gonadotropin-dependent follicle development. J Clin Investig 2003;112:659-669. [PubMed: 12952915]

6. Manau D, Fábregues F, Peñarrubia J, Creus M, Carmona F, Casals G, et al. Vascular endothelial growth factor levels in serum and plasma from patients undergoing controlled ovarian hyperstimulation for IVF. Hum Reprod 2007;3:669-75. [PubMed: 17079244]

7. Agrawal R, Conway G, Sladkevicius P, Tan SL, Engmann L, Payne N, et al. Serum vascular endothelial growth factor and Doppler blood flow velocities in in vitro fertilization: relevance to ovarian hyperstimulation syndrome and polycystic ovaries. Fertil Steril 1998;71:287-293. [PubMed: 9988400]

8. Lemberger T, Desvergne B, et al. Peroxisome proliferator-activated receptors: a nuclear receptor signaling pathway in lipid physiology. Annu Rev Cell Dev Biol 1996;12:335-63. [PubMed: 8970730]

9. Froment P, Gizard F, Defever D, Staels B, Dupont J, Monget P. Peroxisome proliferator-activated receptors in reproductive tissues: from gametogenesis to parturition. J Endocrinol 2006;189:199-209. [PubMed: 16648288]

10. Komar CM. Peroxisome proliferator-activated receptors (PPARs) and ovarian function - implications for regulating steroidogenesis, differentiation, and tissue remodeling. Reprod Biol Endocrinol 2005;3:41. [PubMed: 16131403]

11. Panigrahy D, Singer S, Shen LQ, Butterfield CE, Freedman DA, Chen EJ, et al. PPAR gamma ligands inhibit primary tumor growth and metastasis by inhibiting angiogenesis. J Clin Investig 2002;110:923-932. [PubMed: 12370270]

12. Peeters LLH, Vigne J, Tee MK, Zhao D, Waite LL, Taylor RL. PPAR gamma represses VEGF expression in human endometrial cells: implications for uterine angiogenesis. Angiogenesis 2005;8:373-379. [PubMed: 16400517]

13. Nair AK, Peegal H, Menon KMJ. The role of luteinizing hormone/human chorionic gonadotropin receptor-specific mRNA binding protein in regulating receptor expression human ovarian granulosa cells. J Clin Endocrinol Metabol 2006;91(6):2239-2243.

14. Asimakopoulos B, Nkolettos N, Nehls B, Diedrich K, Al-Hasani S, Metzen E. Gonadotropin-releasing hormone antagonists do not influence the secretion of steroid hormones but affect the secretion of vascular endothelial growth factor from human granulosa luteinized cell cultures. Fertil Steril 2006;86(3):363-641.

15. Ferry G, Bruneau V, Beauverger P, Goussard M, Rodriguez M, Lamamy V, et al. Binding of prostaglandins to human PPAR $\gamma$ : tool assessment and new natural ligands. Eur J Pharmacol 2001;417:77-89. [PubMed: 11301062]

16. Xin X, Yang S, Kowalski J, Gerritsen ME. Peroxisome proliferators-activated receptor- $\gamma$ ligands are potent inhibitors of angiogenesis in vitro and in vivo. J Biol Chem 1999;274(9):9916-9121.

17. McClure N, Healy DL, Rogers PAW, Sullivan J, Beaton L, Haning RV, et al. Vascular endothelial growth factor as capillary permeability agent in ovarian hyperstimulation syndrome. Lancet 1994;344:235-236. [PubMed: 7913160]

18. Gómez R, Simón C, Remohi J, Pellicer A. Vascular endothelial growth factor receptor-2 activation induces vascular permeability in hyperstimulated rates, and this effect is prevented by receptor blockage. Endocrinology 2002;143:4339-4348. [PubMed: 12399430]

19. Koos RD, Olson CE. Hypoxia stimulates expression of the gene for vascular endothelial growth factor (VEGF), a putative angiogenic factor, by granulosa cells of the ovarian follicle, a site of angiogenesis. J Cell Biol 1991;115:421a.

20. Yamamoto S, Konishi I, Tsuruta Y, Nanbu K, Mandai M, Kuroda H, et al. Expression of vascular endothelial growth factor (VEGF) during folliculogenesis and corpus luteum formation in the human ovary. Gynecol Endocrinol 1997;11:371-381. [PubMed: 9476086] 
21. Neulen J, Yan Z, Raczek S, Weindel K, Keck C, Weich HA, et al. Human chorionic gonadotropindependent expression of vascular endothelial growth factor/vascular permeability factor in human granulosa cells: importance in ovarian hyperstimulation syndrome. J Clin Endocrinol Metab 1995;80 (6):1967-1971. [PubMed: 7775647]

22. Kosaka K, Fujiwara H, Yoshioka S, Fujii S. Vascular endothelial growth factor production by circulating immune cells is elevated in ovarian hyperstimulation syndrome. Hum Reprod 2007;22 (6):1647-1651. [PubMed: 17356124]

23. Villasante A, Pacheco A, Pau E, Ruiz A, Pellicer A, García-Velasco JA. Soluble vascular endothelialcadherin levels correlate with clinical and biological aspects of severe ovarian hyperstimulation syndrome. Hum Reprod 2008;23(3):662-667. [PubMed: 18216038]

24. Soares SR, Gómez R, Simón C, García-Velasco JA, Pellicer A. Targeting the vascular endoethelial growth factor system to prevent ovarian hyperstimulation syndrome. Hum Reprod Update 2008;14 (4):321-333. [PubMed: 18385260]

25. Manno M, Tomei F, Marchesan E, Adamo V. Cabergoline: a safe, easy, cheap, and effective drug for prevention/treatment of ovarian hyperstimulation syndrome. Eur J Obstet Gynecol Reprod Biol 2005;122:127-128. [PubMed: 16154051]

26. Gómez R, Gonzalez-Izquierdo M, Zimmerman RC, Novella-Maestre E, Alonso-Muriel I, SanchezCriado J, et al. Low-dose dopamine agonist administration blocks vascular endothelial growth factor (VEG-F)-mediated vascular hyperpermeability without altering VEGF receptor 2-dependent lutueal angiogenesis in a rat ovarian hyperstimulation model. Endocrinology 2006;147(11):5400-5411. [PubMed: 16901966]

27. Alvarez C, Martii-Bonmati L, Novella-Maestre E, Sanz R, Gomez R, Fernandez-Sanchez M, et al. Dopamine agonist cabergoline reduces hemoconcentration and ascites in hyperstimulated women undergoing assisted reproduction. J Clin Endocrinol Metab 2007;92:2931-2937. [PubMed: 17456571]

28. Nissen SE, Wolski K. Effect of rosiglitazone on the risk of myocardial infarction and death from cardiovascular causes. NEJM 2007;356(24):2457-2471. [PubMed: 17517853]

29. Lincoff AM, Wolski K, Nicholls SJ, Nissen SE. Pioglitazone and risk of cardiovascular evenets in patients with type 2 diabetes mellitus. JAMA 2007;298(10):1180-1188. [PubMed: 17848652]

30. Lebovitz HE. Differentiating members of the thiazolidinedione class: a focus on safety. Diabetes Metab Res Rev 2002;18:S23-S29. [PubMed: 11921435]

31. Van Gaal L, Scheen AJ. Are all glitazones the same? Diabetes Metab Res Rev 2002;18:S1-S4. [PubMed: 11921431]

32. Klinker DB, Lim HJ, Strawn EY, Oldham KT, Sander TL. An in vivo murine model of rosiglitazone use in pregnancy. Fertil Steril 2006;86(4):1074-1079. [PubMed: 16952358]

33. Minge CE, Bennett BD, Norman RJ, Robker RL. Peroxisome proliferators-activated receptor- $\gamma$ agonist rosiglitazone reverses the adverse effects of diet-induced obesity on oocyte quality. Endocrinology 2008;149(5):2646-2656. [PubMed: 18276752]

34. Haddad GF, Jodicke C, Thomas MA, Williams DB, Aubuchon M. Case series of rosiglitazone used during the first trimester of pregnancy. Reprod Toxicol 2008;26(2):183-184. [PubMed: 18762242] 


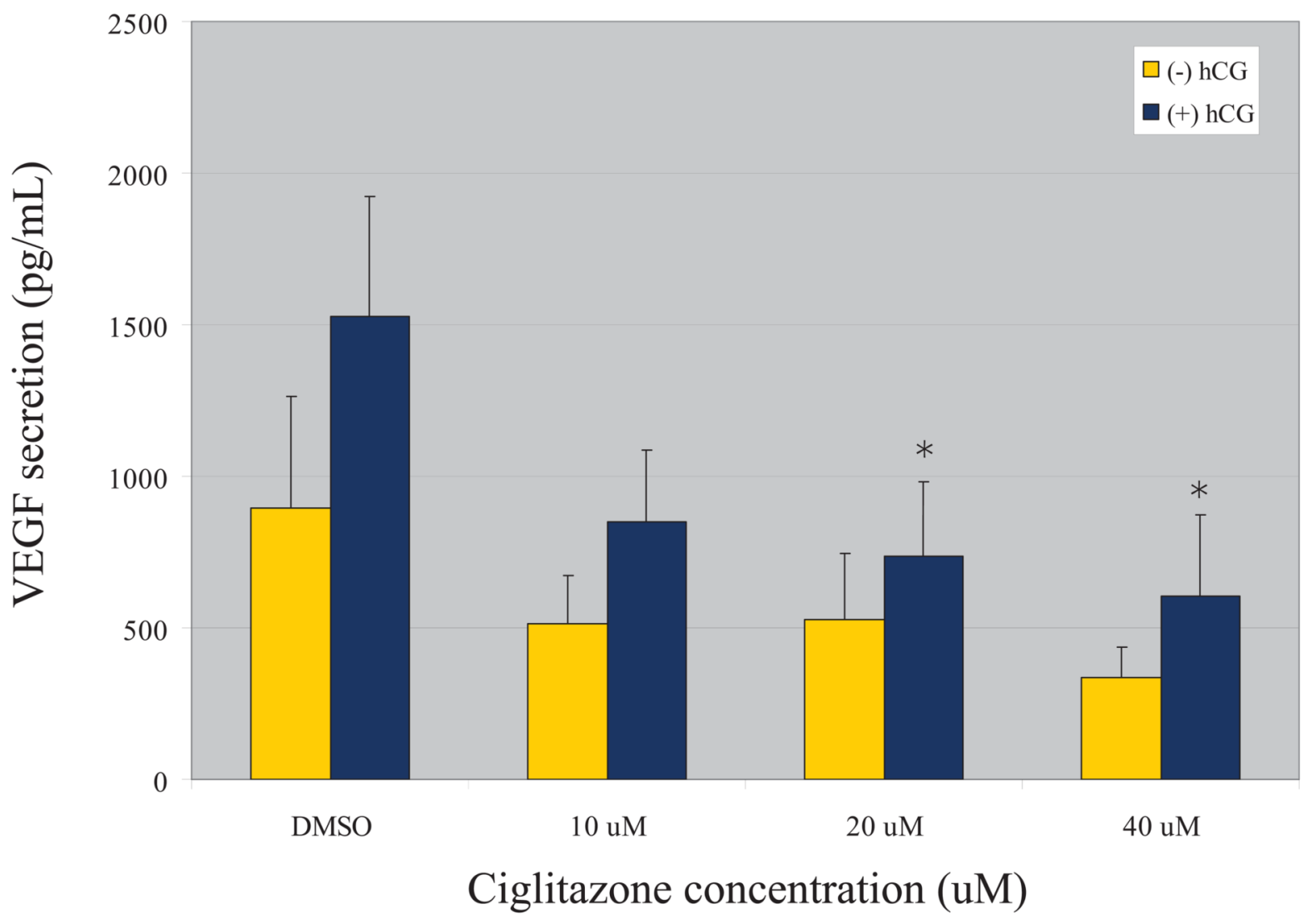

* Compared to DMSO-placebo, $\mathrm{P}<0.001$.

Figure 1.

VEGF production after $24 \mathrm{hrs}$ of ciglitazone treatment

Results are expressed as mean $+/-$ SE. Increasing doses of ciglitazone led to increasing suppression of VEGF protein secretion. In the presence of an hCG stimulus, the $20 \mathrm{uM}$ and 40 $\mathrm{uM}$ concentrations of ciglitazone achieved a statistically significant reduction in VEGF secretion $(\mathrm{P}<0.001)$. 


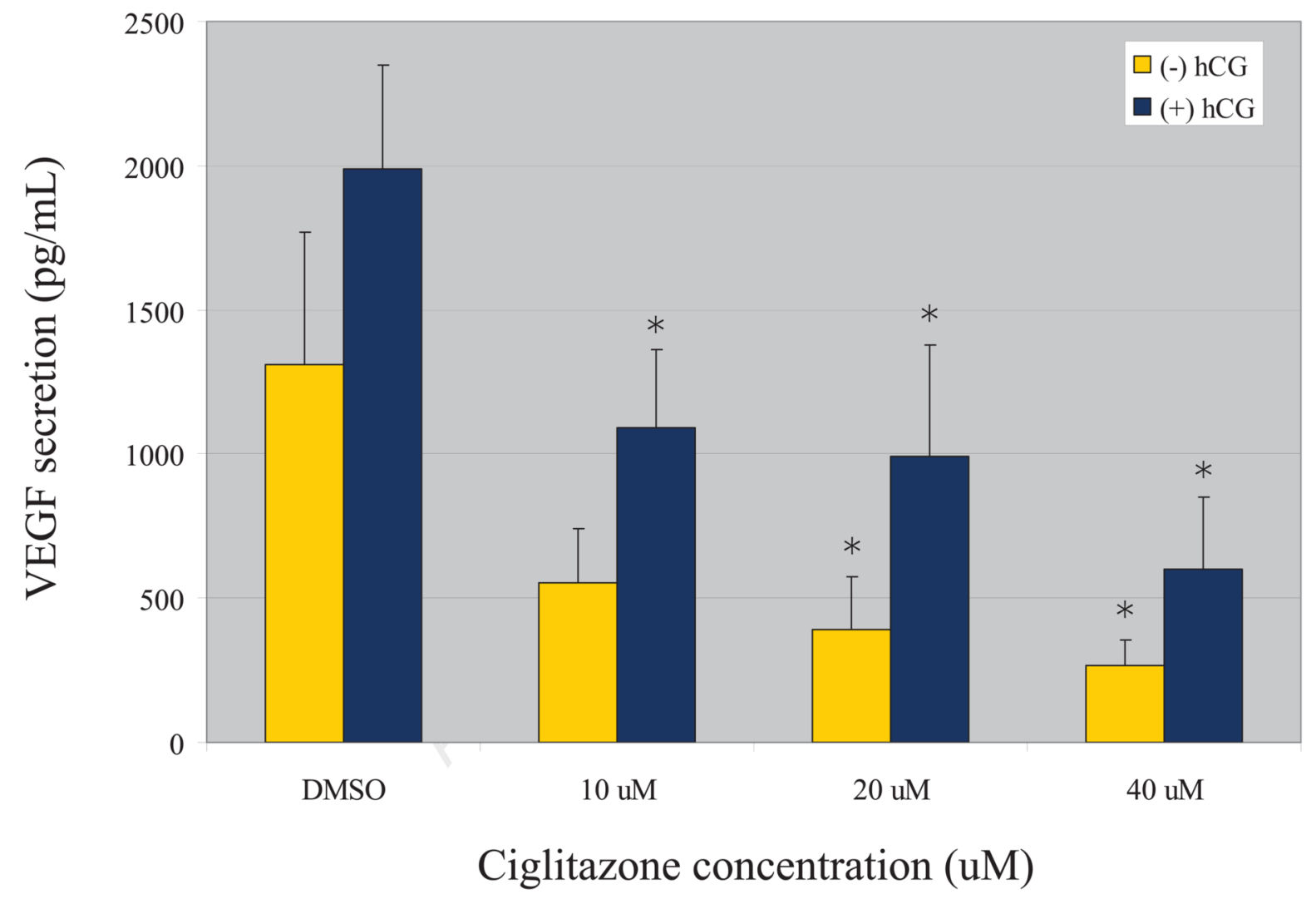

* Compared to DMSO-placebo, $\mathrm{P}<0.001$.

Figure 2.

VEGF production after $48 \mathrm{hrs}$ of ciglitazone treatment

Results are expressed as mean $+/-$ SE. In the presence of an hCG stimulus, each concentration of ciglitazone achieved a statistically significant decrease in VEGF protein secretion as compared with a DMSO control; in the absence of hCG, the $20 \mathrm{uM}$ and $40 \mathrm{uM}$ concentrations achieved statistical significance $(\mathrm{P}<0.001)$. 


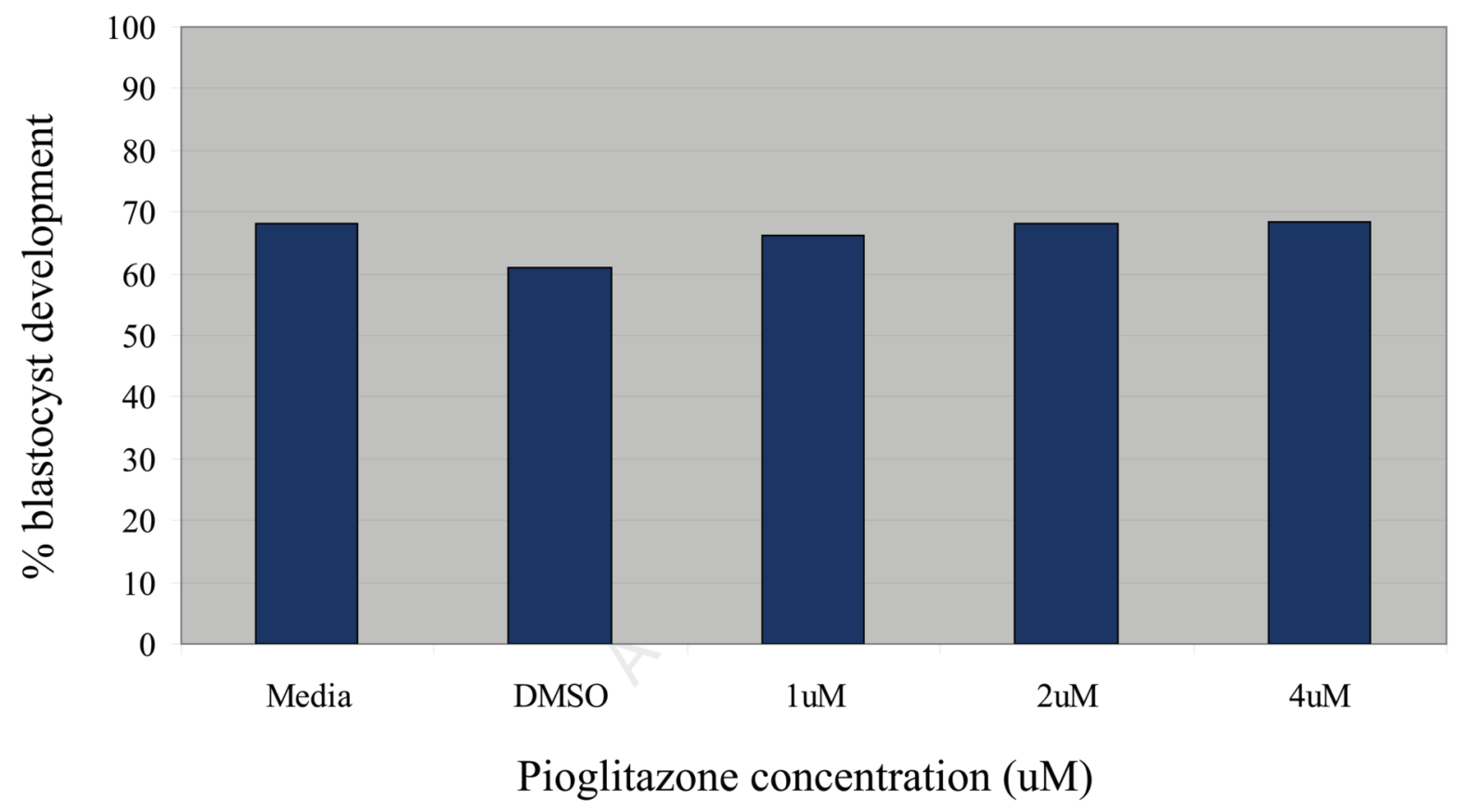

$\mathrm{P}>0.1$ for all treatment groups.

Figure 3.

Impact of pioglitazone on blastocyst development in murine embryos at 96 hours Results are expressed as percentages. There was no significant difference in the percentage of embryos that developed to the blastocyst stage at $\mathrm{t}=96$ hours between the various culture conditions ( $n=100, P>0.1$ for all treatment groups). 


\section{Table 1}

Impact of ciglitazone on granulosa cell proliferation Results are expressed as mean $+/-$ SE. No significant differences in cell proliferation over 48 hours were noted for any of the ciglitazone doses ( $\mathrm{P}>0.1$ for all comparisons).

\begin{tabular}{crc}
\hline Treatment & Mean cell \# at $\mathbf{4 8}$ hrs & \% increase from baseline \\
\hline DMSO & $102,222 \pm 8195$ & $204 \%$ \\
$10 \mu$ ciglitazone & $93,333 \pm 4869$ & $187 \%$ \\
$20 \mu$ ciglitazone & $93,333 \pm 8433$ & $187 \%$ \\
$40 \mu \mathrm{M}$ ciglitazone & $100,000 \pm 8255$ & $200 \%$ \\
\hline
\end{tabular}

$\mathrm{P}>0.1$ for all treatment groups. 